\title{
EFFECTS OF UMBELLIPRENIN ON BLOOD PRESSURE IN HIGH-FAT DIET HYPERTENSIVE RATS
}

\author{
MAHMOUD HASHEMZAEI ${ }^{1 \#}$, TALHEH DOUSTI ${ }^{1}$, KONSTANTINOS TSAROUHAS $^{2}$, \\ GHOLAMREZA BAGHERI ${ }^{3}$, TAXIARCHIS KONSTANTINOS NIKOLOUZAKIS ${ }^{4}$, RAMIN \\ REZAEE $^{5,6 \#}$, JAFAR SHAHRAKI $^{1 *}$ \\ ${ }^{1}$ Department of Pharmacodynamics and Toxicology, School of Pharmacy, Zabol University of Medical Sciences, Zabol, Iran \\ ${ }^{2}$ Department of Cardiology, University Hospital of Larissa, Larissa, Greece \\ ${ }^{3}$ Faculty of Health, Zabol University of Medical Sciences, Zabol, Iran \\ ${ }^{4}$ Center of Toxicology Science \& Research, Medical School, University of Crete, Heraklion, Crete, Greece \\ ${ }^{5}$ Clinical Research Unit, Faculty of Medicine, Mashhad University of Medical Sciences, Mashhad, Iran \\ ${ }^{6}$ Neurogenic Inflammation Research Center, Mashhad University of Medical Sciences, Mashhad, Iran
}

*corresponding author: jafar.shahraki@gmail.com

\# Authors with equal contribution

Manuscript received: November 2019

\begin{abstract}
Umbelliprenin (UMB), a member 7-prenyloxycoumarins, is a sesquiterpene coumarin produced by several Ferula species; UMB presents diverse properties including anticancer, anti-inflammatory and antioxidant activities. Antihypertensive properties of Ferula extracts were attributed to the sesquiterpene coumarins. This work assessed UMB effect on blood pressure in rats treated with high-fat diet (HFD). Forty Wistar rats were randomly assigned into 5 groups of eight: control group (fed with normal diet), HFD-control (fed with HFD (32\% kcal of fat and 1\% cholesterol) for 49 days and normal saline on day 50) and three groups of rats fed with HFD for 49 days and treated with UMB 6.25, 12.5 and $25 \mathrm{mg} / \mathrm{kg}$ (as a single intraperitoneal dose), on day 50. On day 50, invasive blood pressure measurements were made through cannulation of the carotid artery and use of the PowerLab system. Mean arterial blood pressure (MAP), systolic (SBP) and diastolic (DBP) blood pressure and heart rate (HR) were recorded. SBP and MAP in HFD-control rats were significantly higher than those of the control group $(p<0.001)$. Moreover, HFD treated rats that received the higher UMB dose showed a significant decrement of SBP and MAP. UMB presented a favourable anti-hypertensive profile in the HFD hypertension model in rats.
\end{abstract}

\section{Rezumat}

Umbeliprenina (UMB) este o cumarină sesquiterpenică produsă de mai multe specii de Ferula; UMB prezintă proprietăți diverse, inclusiv activități anticanceroase, antiinflamatoare și antioxidante. Proprietățile antihipertensive ale extractelor de Ferula au fost atribuite coumarinelor sesquiterpenice. Această lucrare a evaluat efectul UMB asupra tensiunii arteriale la şobolani tratați cu dietă bogată în grăsimi (HFD). Patruzeci de şobolani Wistar au fost repartizați aleatoriu în 5 grupuri de opt: grup control (dietă normală), control HFD (hrănit cu HFD (32\% kcal de grăsimi şi 1\% colesterol) timp de 49 de zile şi soluție salină normală în ziua 50) și trei grupuri de șobolani hrăniți cu HFD timp de 49 de zile și tratați cu UMB 6,25, 12,5 și $25 \mathrm{mg} / \mathrm{kg}$ corp (doză unică intraperitoneală), în ziua 50. În ziua 50, s-au efectuat măsurători invazive ale tensiunii arteriale prin canularea arterei carotide și utilizarea sistemului PowerLab. Au fost înregistrate presiunea arterială medie (MAP), sistolică (SBP) și diastolică (DBP) și frecvența cardiacă (HR). SBP și MAP la șobolanii-control HFD au fost semnificativ mai mari decât cele ale grupului martor $(\mathrm{p}<0,001)$. Mai mult decât atât, şobolanii tratați cu HFD care au primit doza mai mare de UMB au prezentat o scădere semnificativă a SBP și MAP. UMB a prezentat un profil antihipertensiv favorabil în modelul de hipertensiune arterială HFD la șobolani.

Keywords: umbelliprenin, systolic blood pressure, mean arterial pressure, high-fat diet, rats

\section{Introduction}

Proper management of hypertension as a chronic condition affecting $25 \%$ of general population is of great importance particularly considering the point that a majority of such patients have uncontrolled blood pressure [1, 3]. It was repeatedly shown that hypertension pathophysiology includes a network of multiple interacting vascular effectors. In this context, oxidative stress and endothelial dysfunction were shown in hypertensive individuals and a causal role between them and molecular pathways resulting in hypertension was shown [32].

As primary and adjunctive therapy, the World Health Organization (WHO) emphasizes using non pharmacological measures (like physical activity) and supplementation with antioxidants by subjects with hypertension [6]. Natural antioxidants are able to protect living organisms from oxidative damage due to overwhelming production of reactive oxygen species (ROS) and consequent lipid 
peroxidation and protein/DNA damage $[6,7,9,21$, 23, 27, 29, 34-37]. Plants extracts have been widely examined for their possible effects as antihypertensive agents; for instance, Elaeagnus umbellata extract was shown to have anti-hypertensive effects (24).

Umbelliprenin (UMB) is a 7-prenyloxycoumarin that is synthesized by many Ferula species and presents antioxidant activities. As a sesquiterpene coumarin, UMB has also shown various anti-inflammatory and cancer chemo-preventive activities [13-15, 31]. Another bioactive compound of Ferula, auraptene (7geranyl-oxycoumarin) has shown anti-hypertensive effects $[11,12]$.

To the best of our knowledge, possible effects of UMB on hypertension has not yet been reported; so, in the present work, we aimed to assess UMB effects in high-fat diet (HFD)-hypertensive rats.

\section{Materials and Methods}

\section{Animals}

Forty male Wistar rats ( 8 - 10 weeks old) of $200-250 \mathrm{~g}$ weight, were used in this study. Animals were maintained under standard conditions (at $25^{\circ} \mathrm{C}$ with $12 \mathrm{~h} \mathrm{light} / 12 \mathrm{~h}$ dark cycles) and they had free access to food and water. All animal experiments were approved by the animal research Ethics Committee of University of Medical Sciences of Zabol, Iran, and done in accordance with National Institute of Health Guide for the Care and Use of the Laboratory Animals.

Animals were randomly assigned into 5 groups of eight rats as follows: control group (fed with normal diet), HFD-control (fed with HFD containing 32\% $\mathrm{kcal}$ of fat and $1 \%$ cholesterol for 49 days and normal saline on day 50) and three groups of rats fed with HFD for 49 days and treated with UMB $6.25,12.5$ and $25 \mathrm{mg} / \mathrm{kg}$ (a single intraperitoneal (i.p.) dose), on day 50.

Reagents

Umbelliprenin (UMB; Golexir Pars Co., Mashhad, Iran), ketamine (Alfasan, Holland) and xylazine (Pantex, Holland) were used in this work. For measurement of systolic blood pressure (SBP), diastolic blood pressure (DBP), heart rate (HR) and mean arterial blood pressure (MAP), PowerLab (AD Instruments, Bella Vista, New South Wales, Australia) was used $[18,22]$.

Oral administration of high-fat diet (HFD)

Animals were assigned to receive two types of diet (i.e. normal or HFD). The control group received purified low-fat diet (containing $10.6 \% \mathrm{Kcal}$ of fat) for 7 weeks. The rest of the animals received HFD containing $32 \% \mathrm{Kcal}$ of fat and $1 \%$ cholesterol, for 49 days [4].

Methods

After the 7-week period of HFD, animals were fasted overnight (minimum period of 8 - $10 \mathrm{~h}$ ), and anesthetized using ketamine/xylazine. Animals reflexes were assessed.
Animals were placed on a suitable rodent surgical table with electrocardiogram (ECG) recording. The ventral side of the neck, right hind leg, and chest of the animals were carefully disinfected and shaved. A small incision $(1.5-2.0 \mathrm{~cm})$ was made in rats' neck for the tracheostomy procedure and carotid artery cannulation. Tracheostomy was done by using a small piece of paediatric Ryle's tube or rodent tracheal intubation tube as previously described [10]. The carotid artery was identified and the cardiac end of the blood vessel was clamped by a bulldog clamp for cannulation [22]. The blood vessel was cannulated employing a cannula pre-filled with heparinized normal saline $(0.5 \mathrm{IU} / \mathrm{mL})$. After cannulation, the bulldog clamp at the cardiac end of the blood vessel, was slowly released [31].

Three hours before cannulation, different doses of UMB were injected i.p. in the HFD-UMB groups while the HFD-control group was treated with normal saline. After cannulation, the sensor was connected to the PowerLab instrument and SBP, DBP, MAP and HR were recorded and analysed using LabChart 8 software [22].

Statistical analysis

Data was analysed using SPSS Ver. 11.5 (SPSS, Chicago, IL, USA). Differences among the four groups were assessed using One-way ANOVA followed by Tukey post hoc test. A p $<0.05$ is reported as statistically significant.

\section{Results and Discussion}

Effects of UMB on systolic blood pressure (SBP) in HFD-hypertensive rats

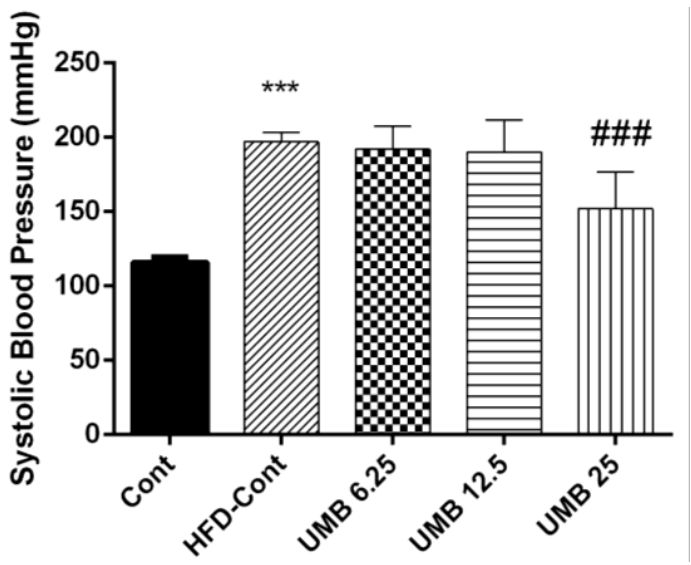

Figure 1.

Effects of different doses of UMB (6.25, 12.5 and $25 \mathrm{mg} / \mathrm{kg}$ i.p) on SBP in rats

(*** $\mathrm{p}<0.001$ compared to the control group and \#\#\# $\mathrm{p}<$ 0.001 compared to HFD-control group. Cont: control group; HFD-Cont: HFD-treated rats that were treated with normal saline on day 50; UMB 6.25, 12.5 and 25: HFD-treated rats that respectively received a single i.p. dose of UMB (umbelliprenin) $6.25,12.5$ and $25 \mathrm{mg} / \mathrm{kg}$, on day 50. SBP: systolic blood pressure) 
As depicted in Figure 1, HFD-control animals, compared to the control group, showed significant increases in SBP ( $p<0.001$ ). Among the UMB-treated groups, only UMB $25 \mathrm{mg} / \mathrm{kg}$ could significantly decrease HFD-induced SBP ( $p<0.001$ compared to the HFDcontrol group).

Effects of UMB on diastolic blood pressure (DBP) in HFD-hypertensive rats

As shown in Figure 2, no significant differences were found in DBP between the control and HFD-control groups. Therefore, our results confirmed that DBP was not changed following HFD treatment.

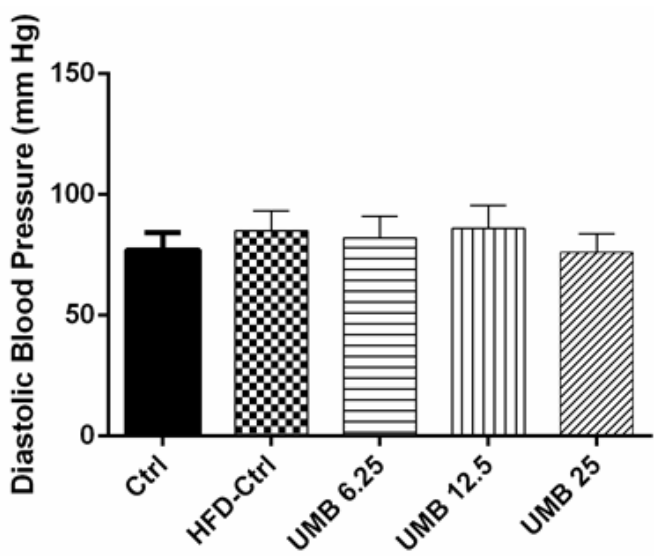

Figure 2.

Effects of different doses of UMB (6.25, 12.5 and 25 $\mathrm{mg} / \mathrm{kg}$ i.p) on diastolic blood pressure (DBP) in rats (Ctrl: control group; HFD-Ctrl: HFD-treated rats that were treated with normal saline on day 50; UMB 6.25, 12.5 and 25: HFD-treated rats that respectively received a single i.p. dose of UMB (umbelliprenin) 6.25, 12.5 and $25 \mathrm{mg} / \mathrm{kg}$, on day 50 )

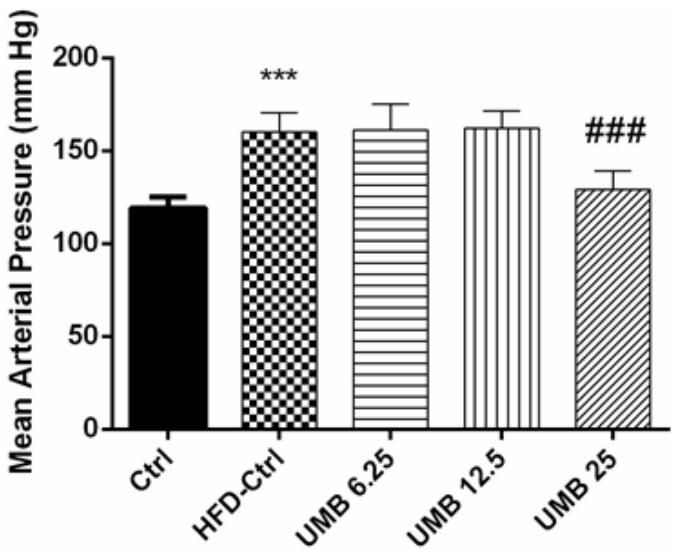

Figure 3.

Effects of UMB on mean arterial pressure (MAP) in rats

(*** $\mathrm{p}<0.001$ compared to the control group and \#\# $\mathrm{p}<$ 0.001 compared to the HFD-Ctrl group. Ctrl: control group; HFD-Ctrl: HFD-treated rats that were treated with norma saline on day 50; UMB 6.25, 12.5 and 25: HFD-treated rats that respectively received a single i.p. dose of UMB (umbelliprenin) $6.25,12.5$ and $25 \mathrm{mg} / \mathrm{kg}$, on day 50)
Effects of UMB on mean arterial pressure $(M A P)$ in HFD-hypertensive rats

Compared to the control group, as depicted in Figure 3, a significant increase in MAP was found in HFDcontrol rats $(\mathrm{p}<0.001)$. Furthermore, UMB $25 \mathrm{mg} / \mathrm{kg}$ significantly reduced MAP compared to the HFDcontrol group ( $p<0.001)$. Nevertheless, no significant differences were found between HFD animals receiving lower doses of UMB (6.25 and $12.5 \mathrm{mg})$ and HFDcontrol group.

Effects of $U M B$ on heart rate (HR) in HFD-hypertensive rats

As depicted in Figure 4, HR did not significantly vary between the control and HFD-treated animals. Further, in the HFD-treated animals, UMB (6.25, 12.5 and $25 \mathrm{mg} / \mathrm{kg}$ ) treatment did not significantly affect HR.

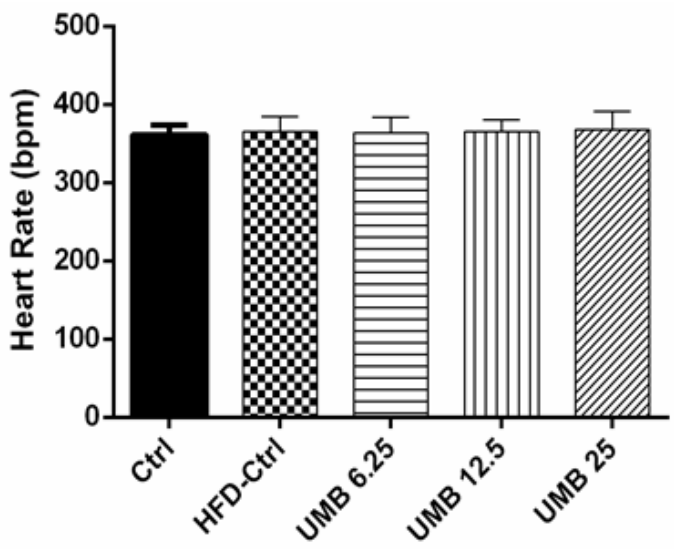

Figure 4.

Effects of different doses of UMB $(6.25,12.5$ and $25 \mathrm{mg} / \mathrm{kg}$ i.p) on heart rate.

(Ctrl: control group; HFD-Ctrl: HFD-treated rats that were treated with normal saline on day 50; UMB 6.25, 12.5 and 25: HFD-treated rats that respectively received a single i.p. dose of UMB (umbelliprenin) $6.25,12.5$ and $25 \mathrm{mg} / \mathrm{kg}$, on day 50 )

In the present study, treatment with a single i.p. dose of UMB $25 \mathrm{mg} / \mathrm{kg}$, decreased SBP and MAP in HFDtreated hypertensive rats. UMB or 7-prenyloxycoumarinis as sesquiterpene coumarins synthesized by many Ferula species and presents diverse effects including anti-inflammatory, antioxidant, cytotoxic, antidiabetic and anti-leishmania effects as well as apoptosis-inducing and anticholinesterase inhibitor properties [25].

One of the most abundant ingredients of Ferula persica is UMB. Ghanbari et al. assessed the antihypertensive effects of Ferula persica in hypertensive rats [5]. They evaluated the acute and chronic effects of different doses of aqueous extract of $F$. persica on hypertensive Wistar rats and found that a single i.v. dose of $F$. persica extract $(15 \mathrm{mg} / \mathrm{kg})$ reduced significantly blood pressure levels in hyper- 
tensive animals whereas the chronic use of this extract did not have any antihypertensive effect. Furthermore, they found that $\mathrm{L}-\mathrm{N}^{\mathrm{G}}$-Nitro arginine methyl ester (LNAME) eliminated and atropine reduced extract's antihypertensive effects (5). Our findings on the shortterm effects of UMB are partially in agreement with the said study showing that UMB, an important ingredient of $F$. persica, was able to reduce blood pressure levels in a 49-day administration period.

Karimi et al. investigated the effects of 8 naturally occurring terpenoid and coumarin derivatives from Ferula including UMB, and found that UMB has acetylcholinesterase inhibitory activity [16]. Several studies showed that peripheral and central acetylcholinesterase inhibition could reduce hypertension [17, 30, 33]. One of these studies conducted by Renata et al. confirmed that donepezil, a strong anticholinesterase inhibitor, attenuated hypertension development in spontaneously hypertensive rats, probably due to its anti-inflammatory properties, indicating that acetylcholinesterase inhibition produces beneficial effects for antihypertensive therapy [30].

UMB was isolated from plants of the genus Ferula [6, 19, 20]. One of the said plants is Ferula gummosa. In the study of Mahmoody et al., it was found that supplementation with Ferula gummosa combined with aerobic training in hypertensive rats, significantly augmented the components of the cardiac apelinergic system and reduced oxidative stress in hypertensive rats [19]. The combination of exercise with $F$. gummosa supplementation increased NO production, which led to a lower blood pressure. One of the active compounds of $F$. gummosa is UMB which probably contributes to its anti-hypertensive effect. Our findings could be interpreted in part by the findings of the said study on the normalization of oxidative stress markers and the up-regulation of the apelinergic system in hypertensive animals [19].

Nitric oxide synthase inhibition induces hypertension and L-NAME can induce hypertension in animal models. In the study by Moosavi et al., F. gummosa hydroalcoholic extract inhibited renal oxidative stress and inflammation induced by L-NAME [20]. In this model of salt sensitive hypertension, $F$. gummosa, an abundant source of UMB, reduced the levels of key players of hypertension induction, renal inflammation and oxidative stress.

Prenylated coumarins are naturally occurring compounds found in vegetables which we are daily consumed [8, $28,36]$. UMB is one of these compounds with a structure similar to auraptene (AUR), another prenylated coumarin from Ferula species [38]. The only chemical difference between these two compounds is that the 7-prenyloxy chain is longer $[2,38]$. Antihypertensive effects of AUR were reported by previous studies $[12,26]$. In rats with hypertension caused by deoxycorticosterone acetate salt, chronic administration of AUR led to a significant blood pressure decrease. At the same time, a single i.v injection of AUR was found to have medium antihypertensive effects in normotensive rats $[12,26]$. Considering the chemical similarity of UMB and AUR, antihypertensive properties might be probably a general characteristic of prenylated coumarins.

\section{Conclusions}

The present study showed the anti-hypertensive effects of UMB and specifically, it indicated that a single i.p. dose of UMB at the concentration of $25 \mathrm{mg} / \mathrm{kg}$ significantly diminished blood pressure in HFD-induced hypertensive rats. UMB as a natural product found in several Ferula species, possesses anti-inflammatory and anti-oxidant properties and together with its antihypertensive action presented for the first time in the current study, seems to be a very promising compound for further evaluation for management of early stages of hypertension.

\section{Conflict of interest}

The authors declare no conflict of interest.

\section{References}

1. Akinyemi AJ, Adedara IA, Thome GR, Morsch VM, Rovani MT, Mujica LKS, Duarte T, Duarte M, Oboh G, Schetinger MRC, Dietary supplementation of ginger and turmeric improves reproductive function in hypertensive male rats. Toxicol Rep., 2015; 2 : 1357-1366.

2. Barthomeuf C, Lim S, Iranshahi M, Chollet P, Umbelliprenin from Ferula szowitsiana inhibits the growth of human M4Beu metastatic pigmented malignant melanoma cells through cell-cycle arrest in G1 and induction of caspase-dependent apoptosis. Phytomedicine, 2008; 15: 103-111.

3. Diaconu CC, Dragoi CM, Bratu OG, Neagu TP, Pantea Stoian A, Cobelschi PC, Nicolae AC, Iancu MA, Hainarosie R, Stanescu AMA, New approaches and perspectives for the pharmacological treatment of arterial hypertension. Farmacia, 2018; 66(3): 408-415.

4. Dobrian AD, Davies MJ, Prewitt RL, Lauterio TJ, Development of Hypertension in a rat model of dietinduced obesity. Hypertension, 2000; 35: 1009-1015.

5. Ghanbari M, Zahedi Khorasani M, and Vakili A. Acute and chronic effects of Ferula persica on blood pressure of hypertensive rats and its possible mechanism of action. J Med Plants, 2012; 11(43): 62-68.

6. Gholitabar S, Roshan VD, Effect of treadmill exercise and Ferula gummosa on myocardial HSP72, vascular function, and antioxidant defenses in spontaneously hypertensive rats. Clin Exp Hypertens., 2013; 35: 347-354.

7. Hashemzaei M, Abdollahzadeh M, Iranshahi M, Golmakani E, Rezaee R, Tabrizian K, Effects of luteolin and luteolin-morphine co-administration on acute and chronic pain and sciatic nerve ligatedinduced neuropathy in mice. J Complement Integr Med., 2017; 14(1): 1-7. 
FARMACIA, 2020, Vol. 68, 3

8. Hashemzaei M, Entezari Heravi R, Rezaee R, Roohbakhsh A, Karimi G, Regulation of autophagy by some natural products as a potential therapeutic strategy for cardiovascular disorders. Eur J Pharmacol., 2017; 802: 44-51.

9. Hashemzaei M, Karami SP, Delaramifar A, Sheidary A, Tabrizian K, Rezaee R, Shahsavand S, Arsene AL, Tsatsakis AM, Taghdisi SM, Anticancer effects of co-administration of daunorubicin and resveratrol in MOLT-4, U266 B1 and RAJI cell lines. Farmacia, 2016; 64(1): 36-42.

10. Hashemzaei M, Rezaee R, Nabatzehi M, Tsarouhas K, Nikolouzakis TK, Lazopoulos G, Spandidos DA, Tsatsakis A, Shahraki J, Anti-hypertensive effect of crocin and hesperidin combination in high-fat diet treated rats. Exp Ther Med., 2020; 19: 3840-3844.

11. Hashemzaei M, SadeghiBonjar MA, Tabrizian K, Iranshahi M, Iranshahy M, Rezaee R, Evaluation of the analgesic effect of umbelliprenin and umbellipreninmorphine co-administration on the acute, chronic and neuropathic pain. Indian J Pharm Educ., 2015; 49: 121-125.

12. Imenshahidi M, Eghbal M, Sahebkar A, Iranshahi M, Hypotensive activity of auraptene, a monoterpene coumarin from Citrus spp. Pharm Biol., 2013; 51: 545-549.

13. Iranshahi $\mathrm{M}$, Barthomeuf $\mathrm{C}$, Bayet-Robert $\mathrm{M}$, Chollet $\mathrm{P}$, Davoodi D, Piacente S, Rezaee R, Sahebkar A, Drimanetype sesquiterpene coumarins from Ferula gummosa fruits enhance doxorubicin uptake in doxorubicinresistant human breast cancer cell line. $J$ Tradit Complement Med., 2014; 4: 118-125.

14. Iranshahi M, Kalategi $F$, Rezaee $R$, Shahverdi AR, Ito C, Furukawa H, Tokuda H, Itoigawa M, Cancer chemopreventive activity of terpenoid coumarins from Ferula species. Planta Med., 2008; 74: 147-150.

15. Iranshahi M, Rezaee R, Sahebkar A, Bassarello C, Piacente S, Pizza C, Sesquiterpene coumarins from the fruits of Ferula badrakema. Pharm Biol., 2009; 47: 344-347.

16. Karimi G, Iranshahi M, Hosseinalizadeh F, Riahi B, Sahebkar A, Screening of acetylcholinesterase inhibitory activity of terpenoid and coumarin derivatives from the genus Ferula. Pharmacologyonline, 2010; 1: 566-574.

17. Lataro RM, Silva CAA, Tefé-Silva C, Prado CM, Salgado HC, Acetylcholinesterase inhibition attenuates the development of hypertension and inflammation in spontaneously hypertensive rats. Am J Hypertens., 2015; 28: 1201-1208.

18. Lin HT, Shiou YL, Jhuang WJ, Lee HC, Simultaneous electrocardiography recording and invasive blood pressure measurement in rats. $J$ Vis Exp., 2019; (143): e59115, doi: 10.3791/59115.

19. Mahmoody SA, Gharakhanlou R, Roshan VD, Hedayati M, Individual and concomitant effects of cardioprotective programs on cardiac apelinergic system and oxidative state in L-NAME-induced hypertension. Clin Exp Hypertens., 2013; 35: 20-27.

20. Moosavi SJ, Habibian M, Peeri M, Azarbayjani MA, Nabavi SM, Nabavi SF, Sureda A, Protective effect of Ferula gummosa hydroalcoholic extract against nitric oxide deficiency-induced oxidative stress and inflammation in rats renal tissues. Clin Exp Hypertens., 2015; 37: 136-141.
21. Ojo OA, Ojo AB, Ajiboye BO, Olaiya O, Okesola MA, Boligon AA, de Campos MMA, Oyinloye BE, Kappo AP, HPLC-DAD fingerprinting analysis, antioxidant activities of Tithonia diversifolia (Hemsl.) A. Gray leaves and its inhibition of key enzymes linked to Alzheimer's disease. Toxicol Rep., 2018; 5: 585-592.

22. Parasuraman $\mathrm{S}$ and Raveendran $\mathrm{R}$, Measurement of invasive blood pressure in rats. J Pharmacol Pharmacother., 2012; 3: 172-177.

23. Parathodi Illam S, Hussain A, Elizabeth A, Narayanankutty A, Raghavamenon AC, Natural combination of phenolic glycosides from fruits resists pro-oxidant insults to colon cells and enhances intrinsic antioxidant status in mice. Toxicol Rep., 2019; 6:703-711.

24. Qayyum R, Qamar HM-U-D, Salma U, Khan S, Khan $\mathrm{T}$, Shah AJ, Insight into the cardiovascular activities of Elaeagnus umbellata. Farmacia, 2019; 67(1): 133-139.

25. Rashidi M, Khalilnezhad A, Amani D, Jamshidi H, Muhammadnejad A, Bazi A, Ziai SA, Umbelliprenin shows antitumor, antiangiogenesis, antimetastatic, anti-inflammatory, and immunostimulatory activities in 4T1 tumor-bearing Balb/c mice. J Cell Physiol., 2018; 233: 8908-8918.

26. Razavi BM, Arasteh E, Imenshahidi M, Iranshahi M, Antihypertensive effect of auraptene, a monoterpene coumarin from the genus Citrus, upon chronic administration. Iran J Basic Med Sci., 2015; 18(2): 153-158.

27. Rezaee R, Behravan E, Behravan J, Soltani F, Naderi Y, Emami B, Iranshahi M, Antigenotoxic activities of the natural dietary coumarins umbelliferone, herniarin and 7-isopentenyloxy coumarin on human lymphocytes exposed to oxidative stress. Drug Chem Toxicol., 2014; 37: 144-148.

28. Rezaee R, Mahmoudi M, Abnous K, Zamani Taghizadeh Rabe S, Tabasi N, Hashemzaei M, Karimi G. Cytotoxic effects of crocin on MOLT-4 human leukemia cells. J Complement Integr Med., 2013; 10(1): 105-112.

29. Rezaee R, Monemi A, Bonjar MAS, Hashemzaei M, Berberine alleviates paclitaxel-induced neuropathy. J Pharmacopuncture, 2019; 22: 90-94.

30. Sadoshima S, Ibayashi S, Fujii K, Nagao T, Sugimori $\mathrm{H}$, Fujishima M, Inhibition of acetylcholinesterase modulates the autoregulation of cerebral blood flow and attenuates ischemic brain metabolism in hypertensive rats. J Cereb Blood Flow Metab., 1995; 15: 845-851.

31. Sattar $Z$ and Iranshahi $M$, Phytochemistry and pharmacology of Ferula persica Boiss.: A review. Iran J Basic Med Sci., 2017; 20(1): 1-8.

32. Schulz E, Gori T, Münzel T, Oxidative stress and endothelial dysfunction in hypertension. Hypertens Res., 2011; 34: 665-673.

33. Sharma B, Singh N, Experimental hypertension induced vascular dementia: pharmacological, biochemical and behavioral recuperation by angiotensin receptor blocker and acetylcholinesterase inhibitor. Pharmacol Biochem Behav., 2012; 102: 101-108.

34. Skenderidis P, Kerasioti E, Karkanta E, Stagos D, Kouretas D, Petrotos K, Hadjichristodoulou C, Tsakalof A, Assessment of the antioxidant and antimutagenic activity of extracts from goji berry of Greek cultivation. Toxicol Rep., 2018; 5: 251-257. 
FARMACIA, 2020, Vol. 68, 3

35. Tabeshpour J, Hashemzaei M and Sahebkar A, The regulatory role of curcumin on platelet functions. $J$ Cell Biochem., 2018; 119: 8713-8722.

36. Tabrizian K, Yaghoobi NS, Iranshahi M, Shahraki J, Rezaee R, Hashemzaei M, Auraptene consolidates memory, reverses scopolamine-disrupted memory in passive avoidance task, and ameliorates retention deficits in mice. Iran J Basic Med Sci., 2015; 18: 1014-1019.
37. Tavassoli M, Afshari A, Arsene AL, Mégarbane B, Dumanov J, Bastos Paoliello MM, Tsatsakis A, Carvalho F, Hashemzaei M, Karimi G, Rezaee R, Toxicological profile of Amanita virosa - A narrative review. Toxicol Rep., 2019; 6: 143-150.

38. Ziai SA and Gholami O, Umbelliprenin, a bioactive constituent from the genus Ferula has cytotoxic and apoptotic activity in a dose- and time-dependent manner. Avicenna J Phytomed., 2020; 10: 1-2. 